\title{
Ketahanan Bank Umum Syariah di Indonesia Terhadap Fluktuasi Makroekonomi dalam Negeri dan Suku Bunga Dana Federal Reserve
}

Resilience of Islamic commercial banks in Indonesia against domestic macroeconomic fluctuations and federal reserve fund interest rates

\section{Donna Sita Soraya Kristanti Jatmiko}

Program Studi D4 Keuangan Syariah, Politeknik Negeri Bandung

E-mail: donnadita.ksy15@polban.ac.id

\section{Djoni Djatnika}

Jurusan Akuntansi, Politeknik Negeri Bandung

E-mail: djoni.djatnika@polban.ac.id

\section{Setiawan}

Jurusan Akuntansi, Politeknik Negeri Bandung

E-mail: setiawan@polban.ac.id

\begin{abstract}
The development of banking in a country cannot be separated from internal and external factors that can influence it. The monetary crisis in 1998 and the global financial crisis in 2008 are some examples that show that the banking sector can be affected by the surrounding economic conditions, both from within and outside the country. The purpose of this study is to determine the resilience of Islamic commercial banks in Indonesia if there are shocks that occur in macroeconomics, in this case, namely inflation, exchange rates, Bank Indonesia benchmark interest rate (BI rate), SBIS yields (rSBIS) and Federal Reserve funds interest rates. (FFR). This study uses the Vector Autoregression (VAR) and Vector Error Correction Model (VECM) methods. The conclusion of this study is that Non-Performing Financing (NPF) and Return on Assets (ROA) in Islamic commercial banks in Indonesia tend to be more resistant to fluctuations that occur in domestic macroeconomics and FFR. The Capital Adequacy Ratio (CAR) is relatively stable in responding to a shock, while the Return on Equity (ROE) and Financing Deposit Ratio (FDR) have fluctuated in the long term in other words, they are more vulnerable to shocks and fluctuations that occur in domestic macroeconomic variables and FFR.
\end{abstract}

Keywords: Islamic commercial banks, macroeconomic, federal reserve fund interest rates

\section{Pendahuluan}

Perbankan merupakan salah satu badan usaha yang bergerak di sektor industri keuangan di Indonesia. Keberadaan perbankan penting dalam perkekonomian suatu negara, karena perannya yang menjembatani kebutuhan masyarakat atas pelayanan jasa keuangan maupun fungsi-fungsinya yang memberikan manfaat langsung bagi masyarakat. Setiap negara di dunia dipastikan memiliki bank sebagai salah satu lembaga yang dapat mendukung perekonomian suatu negara, tak terkecuali Indonesia. Dalam pelaksanaan operasional bank umum Indonesia merupakan salah satu negara yang menerapkan Dual Banking System dengan kata lain kegiatan usaha yang bank umum yang diterapkan dibagi menjadi dua jenis yaitu konvensional maupun syariah. 


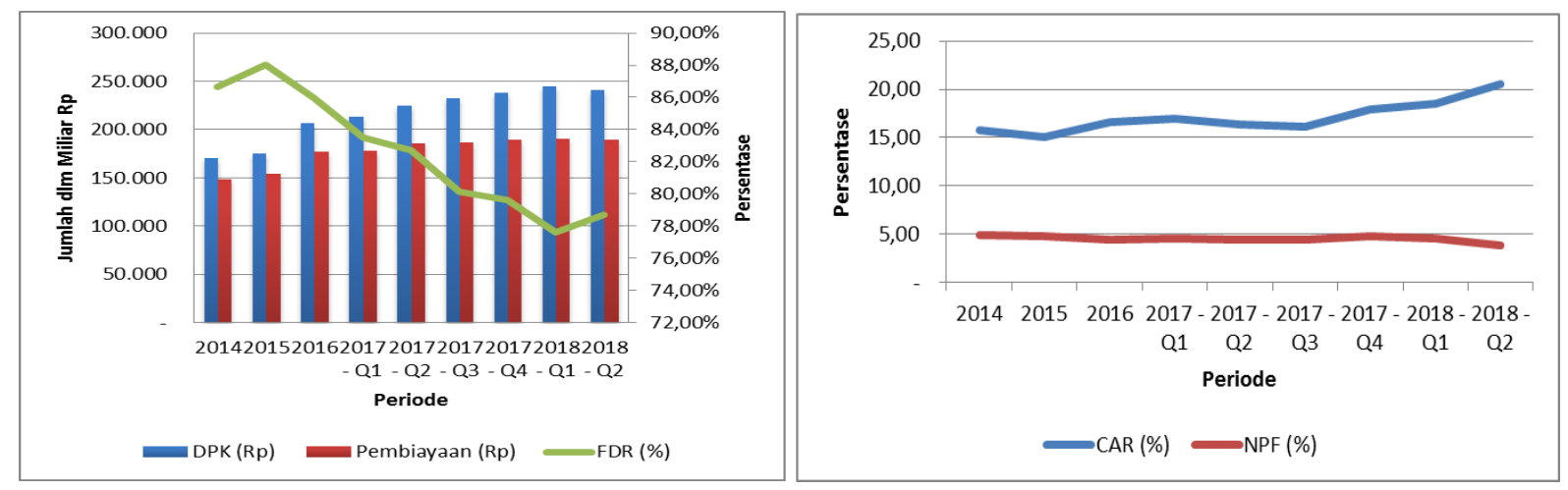

Gambar 1. Perkembangan Bank Syariah

Perkembangan bank syariah di Indonesia diawali dengan muncul nya bank syariah pertama di Indonesia yaitu Bank Muamalat pada tahun 1991. Sejak saat itu bank syariah semakin berkembang di Indonesia, terhitung dalam 10 tahun terakhir sejak tahun 2009 jumlah bank umum syariah di Indonesia mengalami peningkatan menjadi 13 bank umum syariah yang berhasil beroperasi di Indonesia. Perkembangan bank umum syariah tidak hanya dilihat melalui jumlah bank umum yang telah beroperasi, lebih dari itu perkembangan bank umum syariah dapat dilihat melalui kinerja perbankan tersebut. Dua grafik diatas ini menunjukan terjadi peningkatan pula pada dana pihak ketiga (DPK) dan jumlah pembiayaan yang disalurkan. Walaupun data statistik menunjukan bahwa peningkatan yang terjadi tidak terlalu signifikan dan terdapat penurunan pada jumlah DPK dan pembiayaan yang disalurkan pada kuartal 2 tahun 2018 dibandingkan dengan kuartal 1 tahun 2019. Peningkatan yang terjadi pada nominal DPK dan pembiayaan yang disalurkan ternyata berbanding terbalik dengan nilai Financing to Deposit Ratio (FDR). Selain itu perkembangan dari bank syariah pun dapat dilihat melalui Capital Adequacy Ratio (CAR) dan Non Performing Finanor (NPF) yang pada grafik ditunjukan bahwa dalam kurun waktu 5 tahun terakhir, bank umum syariah di Indonesia berhasil menjaga CAR diatas batas minimal yang ditentukan, begitupula dengan NPF Gross yang belum melebihi angka 5\%.

Berdasarkan grafik diatas terlihat bahwa terjadi fluktuasi pada perkembangan kinerja bank umum syariah di Indonesia. Kondisi makroekonomi dalam negeri dapat menjadi salah satu faktor yang mempengaruh kinerja perbankan baik konvensional maupun syariah. Mustai'n dan Fakhrunnas (2018) dalam penelitiannya pula berkesimpulan bahwa faktor makroekonomi seperti tingkat suku bunga Bank Indonesia, tingkat inflasi, dan pertumbuhan GDP memiliki pengaruh yang isgnifikan terhadap kinerja perbankan baik diukur dengan tingkat keuntungan maupun risiko. Selain itu intsrumen-instrumen moneter yang dikeluarkan oleh Bank Indonesia, akan membawa pengaruh pada kinerja perbankan. Tidak terkecuali dengan bank syariah di Indonesia yang memiliki instrumen moneter yang tertera pada Peraturan Bank Indonesia Nomor 10/11/PBI/2008 yaitu Sertifikat Bank Indonesia Syariah.

Banyaknya faktor yang mungkin mempengaruhi kinerja perbankan tidak menutup kemungkinan faktor tersebut timbul dari internal atau eksternal, maupun dalam atau luar negeri. Suku bunga dana Bank Sentral Amerika Serikat, Federal Reserve memiliki potensi untuk mempengaruhi perekonomian dan perbankan di Indonesia. Hal tersebut pernah disampaikan oleh Direktur Investasi PT. Sucor Asset Management dalam kompas.com bahwa kenaikan suku bunga dana Federal reserve (FFR) akan menyebabkan tekanan pada nilai tukar rupiah terhadap dolar Amerika Serikat dan mempengaruhi kebijakan yang diambil Bank Indonesia berkenaaan dengan suku bunga acuan, yang berimbas pada pertumbuhan kredit di perbankan.

Mengetahui pentingnya peran perbankan dalam suatu negara diikuti dengan banyaknya faktor yang dapat mempengaruhi perkembangannya, maka terdapat beberapa penelitian yang 
mengambil topik tentang seberapa kuat dan seberapa tahankah perbankan dalam menghadapi perubahan kondisi perekonomian. Hal tersebut dapat pula dilatarbelakangi dengan berbagai kejadian terdahulu yang menimpa perbankan seperti krisis moneter tahun 1998 yang berimbas pada jatuhnya industri perbankan di Indonesia dan krisis keuangan global tahun 2008. Tidak hanya terjadi di dalam negeri, fenomena ini pun turut dirasakan oleh berbagai negara di dunia. Penelitian atas fenomena ini biasa dilakukan pada perbankan konvensional maupun syariah sebagai objek penelitian dan tak jarang pula dilakukan uji banding ketahanan antara kedua jenis perbankan tersebut.

International Monetary Fund (2010) melakukan sebuah survei melalui pengamatan pada krisis yang terjadi tahun 2008 pada 8 negara di dunia, dilakukan perbandingan antara Bank Syariah dan Konvensional. Hasil dari survei tersebut adalah pembuktian bahwa bank syariah lebih kuat dalam aspek profitabilitas, pembiayaan yang disalurkan, dan total aset dibandingkan dengan bank konvensional pada saat menghadapi krisis keuangan global. Hal yang serupa pun disampaikan oleh Cihak dan Hesse (2008) dalam penelitiannya, disimpulkan bahwa bank syariah dengan skala kecil lebih kuat secara finansial daripada bank konvensional kecil.

Di Indonesia penelitian tentang resistensi perbankan khususnya perbankan syaroah dalam menghadapi krisis keuangan maupun fluktuasi perekonomian pun pernah dilakukan. Faiz (2010) mengemukakan bahwa perbankan syariah dan sistem perekonomian dapat mengurangi dampak dari krisis keuangan global pada masyarakat dalam negeri. Bambang Brodjonegoro dalam sebuah Seminar Nasional Ekonomi Syariah tahun 2015 yang diliput oleh detik.com pun memaparkan hasil dari beberapa studi bahwa bank syariah memiliki daya tahan lebih kuat berhadapan dengan krisis dibandingan bank konvensional. Tidak banyak penelitian yang mengambil perbankan syariah di Indonesia sebagai objek penelitian resistensi perbankan, peneliti biasanya banyak menggunakan perbankan syariah yang memiliki pangsa pasar signifikan di negaranya seperti Bahrain, Jordan, Kuwait, Malaysia, Saudi Arabia, United Emirates Arab, Qatar, dan Turki. Hal ini menjadi salah satu alasan penulis untuk meneliti ketahanan bank syariah di Indonesia. Apakah hasil dari penelitianpenelitian tersebut yang berkesimpulan bahwa bank syariah lebih kuat menghadapi krisis dan fluktuasi perekonomian suatu negara akan sama terjadi di Indonesia?

Mengacu pula pada pemaparan singkat di atas tentang pentingnya peran perbankan dan kondisi bank umum syariah di Indonesia yang sedang berkembang, menjadikan kuat atau tidak nya perbankan syariah menghadapi perubahan kondisi perekonomian secara makro, dan kondisi perubahan lain seperti Fed Fund Rate (FFR) perlu untuk diteliti.

\section{Kajian Pustaka}

\subsection{Ketahanan Bank Umum Syariah}

Ketahanan sektor perbankan dalam menghadapi suatu krisis atau guncangan belum memiliki definisi maupun penjelasan khusus tentang indikator apa saja yang dapat menentukan ketahanan suatu perbankan. Tetapi, di samping itu terdapat beberapa penelitian tentang resistensi perbankan, salah satunya adalah penelitian yang dipublikasikan oleh Bank Indonesia pada tahun 2003 tentang Indikator Awal Krisis Perbankan. Dalam penelitian tersebut Hadad dkk. (2003) menjelaskan bahwa terdapat 6 indikator yang dapat digunakan untuk melihat potensi krisis suatu perbankan yaitu pertumbuhan PDB riil yang melambat, konsumsi swasta yang makin meningkat, penurunan tingkat investasi, depresiasi tajam nilai tukar, pemberian kredit kepada sektor swasta yang makin intensif, dan penurunan jumlah simpanan masyarakat yang berkelanjutan.

Seperti yang telah dipaparkan pada bab sebelumnya bahwa sistem perbankan terus mengalami perkembangan baik di dalam maupun luar negeri. Perkembangan ini pun mengakibatkan masalah perbankan yang ada tidak hanya dialami oleh sektor perbankan konvensional, melainkan perbankan syariah pun tidak luput dari berbagai masalah termasuk 
permasalahan yang disebabkan oleh suatu krisis. Terdapat berbagai pendapat mengenai variabel apa saja yang dapat digunakan untuk menilai ketahanan perbankan syariah dalam menghadapi suatu guncangan, dimana variabel tersebut dapat timbul dari internal maupun eksternal perbankan. Kinerja keuangan perbankan yang dilihat melalui rasio-rasio keuangan dapat dijadikan sebagai variabel pengamatan. Hal tersebut dilakukan oleh Zarrouk (2014) yang menggunakan rasio profitabilitas, likuiditas, risiko dan solvabilitas, serta efisiensi sebagai dasar pengamatan performa keuangan bank syariah saat terjadi krisis keuangan tahun 2008.

\subsection{Kinerja Bank Umum Syariah}

Gambaran kinerja serta baik buruknya suatu perbankan pada umumnya dan termasuk bank syariah, biasanya tercermin dalam laporan keuangan yang ditunjukan oleh nilai dari rasio keuangan perusahaan perbankan tersebut (Suwiknyo, 2016: 145-147). Dari berbagai jenis rasio keuangan yang dapat digunakan sebagai alat ukur, penelitian ini menggunakan beberapa rasio keuangan yang dapat menunjukan kinerja bank umum syariah yaitu Non Performing Financing (NPF), Return on Asset (ROA), Return on Equity (ROE), Capital Adequacy Ratio (CAR), dan Financing to Deposit Ratio (FDR).

\subsection{Fluktuasi Makroekonomi Dalam Negeri}

Ekonomi makro atau makroekonomi adalah studi tentang ekonomi secara keseluruhan dimana menjelaskan perubahan ekonomi yang mempengaruhi banyak rumah tangga (bousehold) dan perushaan serta pasar (Prasetyo, 2016:5). Beberapa variabel agregatif yang berhubungan dengan makro ekonomi adalah pengeluaran konsumsi, investasi nasional, jumlah uang beredar, tingkat suku bunga, tingkat inflasi, tingkat kesempatan kerja, neraca pembayaran internasional, serta stok kapital pemerintah dan hutang pemerintah. Makroekonomi pula mencakup pertumbuhan pendapatan, perubahan harga, dan tingkat pengangguran. Para pelaku makroekonomi bertugas untuk menjelaskan peristiwa ekonomi dan menentukan kebijakan-kebijakan untuk meningkatkan kinerja ekonomi (Mankiw, 2009:15).

Makroekonomi berhubungan dengan segala peristiwa ekonomi secara agregat atau makro dalam suatu negara (Tripuspitorini \& Setiawan, 2020). Disampaikan oleh Villaverde dari University of Pennsylvania bahwa pertumbuhan dan fluktuasi merupakan hal terpenting dalam makroekonomi. Adanya kemungkinan terjadinya fluktuasi perekonomian secara makro yang akan berdampak pada perekonomian secara mikro. Diperkuat oleh pendapat Mankiw (2009) peristiwa makroekonomi timbul dari interaksi perekonomian mikro. Hal tersebut mengakibatkan pemerintah dan para pemangku kebijakan akan menjadi pihak yang sangat menentukan arah kebijakan yang diambil sehubungan dengan ekonomi secara makro.

Setiap negara di dunia tidak akan terlepas dari peristiwa ekonomi makro yang akan terjadi di dalam negerinya, termasuk Indonesia. Fluktuasi perekeonomian makro dalam negeri akan selalu menjadi perhatian pemerintah, dengan tujuan menjaga perekeonomian tetap stabil sebagai salah satu tujuan makroekonomi secara fundamental (Prasetyo, 2016:195) dan tidak mengganggu perekonomian dalam lingkup mikro. Salah satu sektor yang akan terkena dampak dari fluktuasi perekonomian makro adalah perbankan. Castro (2012) dalam penelitiannya berkesimpulan bahwa kredit perbankan secara signifikan dipengaruhi oleh lingkungan makroekonomi. Hal serupa terjadi pada perbankan di Indonesia, Dwijayanthi dan Naomi (2009) menemukan bahwa inflasi dan nilai tukar mata uang (kurs) terbukti berpengaruh pada profitabilitas perbankan.

Perbankan syariah pun tidak luput dari pengaruh fluktuasi faktor-faktor makro ekonomi. Sebagai contoh total simpanan bank syariah di Malaysia dipengaruhi secara negatif signifikan oleh tingkat inflasi sebagai salah satu faktor makroekonomi (Abduh dkk, 2011). Kinerja keuangan perbankan syariah di Indonesia dapat dipengaruhi oleh faktor-faktor makroekonomi dalam negeri, hal ini disampaikan oleh Sahara (2013) bahwa inflasi, suku bunga, dan produk domestik bruto (PDB) memiliki pengaruh signifikan pada ROA perbankan. Sehingga variabel makroekonomi 
dalam negeri yang digunakan dalam penelitian ini adalah inflasi, nilai tukar mata uang rupiah terhadap dolar amerika serikat (kurs), suku bunga acuan Bank Indonesia (BI rate), imbal hasil SBIS (rSBIS).

\subsection{Suku Bunga Dana Federal Reserve (Fed Funds Rate)}

Federal Reserve atau secara informal biasa disebut dengan The Fed merupakan Bank Sentral Amerika Serikat. The Fed didirikan oleh presiden ke 28 Amerika Serikat bernama Woodrow Wilson pada tanggal 23 Desember 1913. Bank ini didirikan sebagai bentuk kebutuhan akan kesstabilan keuangan dan perekonomian saat itu karena Amerika Serikat pernah mengalami beberapa krisis keuangan pada abad 19 hingga awal abad ke-20. Beberapa faktor yang berkontribusi pada krisis tersebut adalah kegagalan beberapa perbankan, dimana hal tersebut berdampak pada gelombang kepanikan perbankan dan ketidakstabilan perekonomian.

The Fed memiliki dua fungsi utama yaitu untuk menghadirkan mata uang yang elastis dan untuk membentuk pengawasan yang lebih efektif terhadap industri perbankan nasional (Federal Reserve Bank of Philadelphia, 2014). Ditambah pula dengan peran bank sentral yang tidak terlepas dari fungsi moneter, dan pada tahun 1927 The Fed melanjutkan kebijakan moneter efektifnya dengan meningkatkan jumlah uang beredar untuk membuat kredit agar lebih mudah diperoleh. Terdapat perubahan pada perekonomian nasional setlah adanya The Fed diantaranya: perekonomian kembali pulih, institusi keuangan menjadi lebih kuat, suku bunga stabil, resesi telah berjangka pendek, pemulihan berlangsung cepat, dan cadangan emas meningkat.

The Fed terus mengalami perkembangan dan penyesuain dengan berbagai peristiwa ekonomi yang terjadi saat itu. Pada tahun 1933 The Fed membentuk Federal Open Market Committee (FOMC) dan pada tahun 1935 mulai ditentukan tugas dari FOMC. FOMC merupakan bagian utama dari Federal Reserve System untuk membuat keputusan kebijakan moneter. Di dalam struktur FOMC terdapat Open Market Trading Desk yang beroperasi masing-masing didalam distriknya. Open Market Trading Desk melakukan operasi pasar terbuka harian, membeli atau menjual sekuritas pemerintah Amerika Serikat di pasar terbuka, sebagaimana diperlukan untuk mencapai Suku Bunga Dana Federal Reserve (Federal Funds Rates/FFR). (Federal Reserve Bank of Philadelphia, 2014).

Pinjam meminjam cadangan dana terjadi di Pasar Dana Federal (Federal Funds Market) pada tingkat bunga yang ditentukan secara kompetitif yang dikenal sebagai Fed Funds Rate (Goodfriend dan Whelpley, 1986). Menurut Purnarawan (2016) FFR adalah suku bunga antar bank sebagai biaya pinjam-meminjam cadangan bank (bank reserves) yang ditempatkan oleh perbankan umum pada bank sentral Amerika Serikat dalam durasi semalam (overnight). Proses ini dilakukan tanpa menggunakan agunan. FFR ditetapkan oleh FOMC melalui Open Market Trading Committe.Dalam perjalanannya FFR menjadi variabel suku bunga yang paling penting dibandingkan dengan seluruh jenis suku bunga yang lain. Pengaruh FFR menyebar mempengaruhi perekeonomian seluruh penjuru dunia.

\subsection{Penelitian Terdahulu}

Terdapat beberapa penelitian terdahulu yang menjadi rujukan penulis dalam melakukan penelitian pada tugas akhir ini. Rujukan penelitian ini memiliki topik yang serupa dengan judul penenlitian penulis yaitu mengenai ketahanan bank syariah dalam menghadapi fluktuasi maupun guncangan yang berasal dari lingkungan eksternal perusahaan, terutama dari segi makroekonomi. Beberapa penelitian yang menjadi rujukan penulis menggunakan objek bank syariah yang berada di luar negara Indonesia. Sampel perbankan syariah yang digunakan mayoritas berada pada negara dengan pangsa pasar bank syariah yang cukup tinggi. Sebagian besar penelitian menyimpulkan bahwa bank syariah cenderung resisten terhadap guncangan pada variabel-variabel makroekonomi maupun krisis keuangan yang terjadi di dalam dan di luar negara tempat bank syariah tersebut 
beroperasi.

Cihak dan Hesse (2008) dalam penelitiannya mengungkapkan bahwa bank syariah kecil lebih kuat secara financial bila dibandingkan dengan bank konvensional kecil. Riset yang dilakukan oleh Internatinal Monetaruy Fund (IMF) pada tahun 2010 bahwa bank syariah lebih kuat dalam aspek profitabilitas, kredit yang disalurkan, dan total aset dibandingkan dengan bank konvensional pada saat menghadapi krisis keuangan global. Hal serupa pula disampaikan oleh Farooq dan Zaheer (2015) bahwa bank syariah cenderung memberikan lebih banyak kredit selama kepanikan keuangan. Penelitian yang memiliki hasil yang bertolak belakang dengan beberapa penelitian sebelumnya adalah penelitian yang dilakukan oleh Zarrouk (2014) yang menggunakan sampel bank syariah yang merupakan anggota dari GCC (GulfCooperation Council) atau lebih dikenal dengan Dewan Kerjasama untuk Negara Arab di Teluk dan negara di Afrika Utara. Penelitian ini menyatakan bahwa institusi keuangan syariah cenderung tidak imun terhadap dampak dari resesi keuangan global.

Penelitian mengenai resistensi bank syariah di Indonesia pernah dilakukan oleh Faiz (2010) dan Nugraheni (2011). Faiz berfokus pada resistensi atau ketahanan kredit dari perbankan syariah terhadap krisis keuangan global dan berkesimpulan bahwa NPL pada bank syariah resisten terhadap krisis keuangan. Penelitian Nugraheni pun menyatakan bahwa NPF dan ROA lebih stabil hasilnya apabila terdapat guncangan makroekonomi, tetapi tidak dengan ROE yang memiliki dampak yang lebih berfluktuatif.

\section{Metode Penelitian}

Jenis data yang digunakan adalah data sekunder kuartalan atau triwulanan periode kuartal satu 2014 sampai dengan kuartal empat 2018. Sumber data didapat dari Laporan Keuangan Publikasi Perbankan Syariah di Indonesia - Bank Indonesia, Statistik Perbankan Syariah - Otoritas Jasa Keuangan, Badan Pusat Statistik, Statistik Ekonomi dan Perbankan Indonesia - Bank Indonesia, dan Macrotrends - Federal Funds Rate Historical Charts.

Populasi dari penelitian ini adalah Laporan Keuangan bank umum syariah di Indonesia yang telah beroperasional dari tahun 2014 sampai dengan 2018. Jumlah bank umum syariah di Indonesia terhitung sampai kuartal empat 2018 adalah 13. Terjadi perbedaan jumlah bank umum syariah pada tahun 2014 dan 2015 yaitu sebanyak 12 bank umum syariah yang beroperasi, sehingga penelitimemnentukan bahwa sampel yang digunakan pada penelitian ini adalah 12 bank umum syariah yang telah beroperasi dari tahun 2014 sampai dengan tahun 2018.

Metode penelitian yang digunakan dalam penyusunan tugas akhir ini adalah metode analisa deskriptif melalui studi kepustakaan dan analisa kuantitatif menggunakan metode ekonometrika yaitu VAR (Vector Autoregression) dan VECM (Vector Error Correction Model).

VAR merupakan salah satu model ekonometrik yang merupakan perpanjangan dari model univariate autoregression menuju multivarian data time series, diperkenalkan oleh Christopher A. Sims sebagai alternatif dalam melakukan analisis ekonomi makro. Model VAR memiliki struktur model yang lebih sederhana dengan jumlah variabel yang relatif minimalis dkmana semua variabelnya adalah variabel endogen dengan variabel independennya adalah lag. Desain dari model VAR diperuntukan untuk variabel statisioner yang tidak mengandung trend. Trend stokastik di dalam dalam dapat menghasilkan indikasi bahwa terdapat komponen long-run (jangka panjang) dsan shortrun (jangka pendek) dalam data time series.

Sedangkan VECM merupakan model turunan dari VAR, karena seluruh asumsi yang harus dipenuhi sama seperti VAR kecuali masalah stasioneritas. VECM harus stasioner pada diferensiasi pertama dan semua variabel harus memiliki stasioner yang sama yaitu telah terdeferensiasi pada turunan peetama, VECM sering disebut sebagai desain VAR bagi series nonstasioner yang memiliki hubungan kointegrasi. Model VECM membiarkan dinamisasi jangka pendek dengan merestriksi 
hubungan jangka panjang variabel-variabel endogen agar konvergen (Basuki, 2016).

Terdapat beberapa tahapan yang perlu dilakukan sebelum melakukan uji estimasi VAR atau VECM hingga pada akhirnya dapat memperoleh hasil uji Impuls Response Function (IRF) sebagai alat untuk melihat respon variabel kinerja keuangan bank umum syariah terhadap guncangan yang terjadi pada variabel makroekonomi dalam negeri dan FFR. Tahap yang harus dilewati diantaranya adalah uji stasioneritas, uji panjang lag optimum, uji stabilitas model VAR, dan uji kointegrasi.

\section{Hasil dan Pembahasan}

\subsection{Hasil Uji Stasioneritas}

Uji stasioneritas ini dilakukan pada setiap variabel penelitian, dimana hasil dari uji menunjukan dimana sebuah variabel dalam bentuk data dinyatakan stasioner. Sebuah variabel pengujian dapat stasioner di tingkat level, first difference, maupun second difference. Apabila suatu variabel tidak stasioner di level, maka perlu dilakukan pengujian pada first difference kemudian seterusnya hingga didapatkan variabel yang memenuhi syarat stasioner. Berikut adalah rangkuman hasil pengujian stasioneritas variabel penelitian yang dilakukan pada ketiga tingkatan:

Tabel 1. Uji Stasionetitas Tingkat Level

\begin{tabular}{|l|c|c|}
\hline \multirow{2}{*}{ Variabel } & \multicolumn{2}{|c|}{ Uji Stasioneritas } \\
\cline { 2 - 3 } & Prob. & Hasil \\
\hline NPF & 0,000 & Stasioner \\
\hline ROA & 0,000 & Stasioner \\
\hline ROE & 0,000 & Stasioner \\
\hline CAR & 0,000 & Stasioner \\
\hline FDR & 0,000 & Stasioner \\
\hline INF & 0,000 & Stasioner \\
\hline lnKURS & 0,000 & Stasioner \\
\hline BIRATE & 0,000 & Stasioner \\
\hline rSBIS & 0,000 & Stasioner \\
\hline FFR & 0,000 & Stasioner \\
\hline
\end{tabular}

Catatan : Nilai yang tercantum adalah probabilitas pada lag 1

Tabel 2. Uji Stasioneritas Tingkat First Difference

\begin{tabular}{|l|c|c|}
\hline \multirow{2}{*}{ Variabel } & \multicolumn{2}{|c|}{ Uji Stasioneritas } \\
\cline { 2 - 3 } & Prob. & Hasil \\
\hline NPF & 0,081 & Tidak Stasioner \\
\hline ROA & 0,000 & Stasioner \\
\hline ROE & 0,000 & Stasioner \\
\hline CAR & 0,000 & Stasioner \\
\hline FDR & 0,000 & Stasioner \\
\hline INF & 0,000 & Stasioner \\
\hline lnKURS & 0,820 & Tidak Stasioner \\
\hline BIRATE & 0,000 & Stasioner \\
\hline rSBIS & 0,232 & Tidak Stasioner \\
\hline FFR & 0,000 & Stasioner \\
\hline
\end{tabular}

Catatan : Nilai yang tercantum adalah probabilitas pada lag 1 
Tabel 3. Uji Stasioneritas Tingkat Second Difference

\begin{tabular}{|l|c|c|}
\hline \multirow{2}{*}{ Variabel } & \multicolumn{2}{|c|}{ Uji Stasioneritas } \\
\cline { 2 - 3 } & Prob. & Hasil \\
\hline NPF & 0,000 & Stasioner \\
\hline ROA & 0,000 & Stasioner \\
\hline ROE & 0,000 & Stasioner \\
\hline CAR & 0,187 & Tidak Stasioner \\
\hline FDR & 0,000 & Stasioner \\
\hline INF & 0,000 & Stasioner \\
\hline lnKURS & 0,000 & Stasioner \\
\hline BIRATE & 0,000 & Stasioner \\
\hline rSBIS & 0,000 & Stasioner \\
\hline FFR & 0,000 & Stasioner \\
\hline
\end{tabular}

Catatan : Nilai yang tercantum adalah probabilitas pada lag 1

Hingga pengujian stasioneritas pada second difference terdapat variabel yang tidak stasioner pada level pengujian, yaitu CAR tetapi pada hasil pengujian stasioneritas. Seperti yang telah dijelaskan pada bab sebelumnya bahwa peniliti memiliki lima model penelitian dimana variabel kinerja keuangan perbankan yang diwakili oleh NPF, ROA, ROE, CAR, FDR dimaksudkan sebagai variabel terikat. Maka dari itu, peneliti memutuskan untuk menggunakan variabel pada level second difference untuk model dengan variabel terikat NPF, ROA, ROE, dan FDR. Sedangkan untuk model penelitian dengan variabel terikatnya adalah CAR, peneliti akan menggunakan data pada tingkat level.

\subsection{Hasil Uji Panjang Lag Optimum}

Pengujian untuk mengetahui panjang lag optimum dilakukan pada kelima model penelitian yang telah dirancangkan oleh penulis sebelumnya. Setelah melakukan pengujian ini, hasil menunjukan bahwa kelima model penelitian memiliki panjang lag optimum sebesar 1 (satu).

\subsection{Hasil Uji Stabilitas Model VAR}

Setelah menguji panjang lag optimum untuk model-model tersebut maka yang harus dilakukan selanjutnya adalah menguji stabilitas model. Pengujian ini dilakukan melalui VAR stability condition check, dimana hal tersebut ditunjukan melaui roots of characteristc polynomial terhadap seluruh variabel yang digunakan dalam suatu model dikaitkan dengan jumlah dari masing-masig VAR (Basuki dan Prawoto, 2016). Menurut Faiz (2010) utuk menghasilkan Impulse Rsponse Function (IRF) dan Forecast Error V ariance Decomposition (FEVD) yang valid maka VAR pada lag optimal harus stabil. Dalam menarik kesimpulan apakah sebuah model stabil atau tidak, hal yang harus diperhatikan adalah nilai modulus seluruh akarnya (modulus roots). Ascarya (2009) dalam penelitiannya mengatakan bahwa suatu model dikatakan stabil apabila nilai modulus akar nya kurang dari satu. Hasil pengujian menunjukan bahwa kelima model lolos uji stabilitas model var, karena nilai modulus akarnya kurang dari satu kecuali pada model CAR. Ketidakstabilan model CAR mengakibatkan penulis harus mengeluarkan variabel FFR pada model tersebut setelah itu dilakukan pengujian kembali dan hasil menunjukan bahwa model CAR tersebut stabil.

\subsection{Hasil Uji Kointegrasi}

Hubungan jangka panjang variabel-variabel dalam suatu penelitian dapat dillihat dengan menggunakan pengujian kointegrasi. Faiz (2016) dalam penelitiannya pula menyatakan bahwa suatu variabel harus memenuhi kriteria proses integrasi untuk memperoleh hubungan jangka panjang apabila variabel ada tingkat level tidak stasioner. Terdapat kemungkinan bahwa suatu model yang didalamnya terdapat variabel-variabel yang tidak memenuhi syarat stasioneritas pada tingkat level 
maka akan dilakukan estimasi menggunakan Vector Error Correction Model (VECM) bukan dengan VAR. Untuk memperjelas penggunaan metode, maka perlu dilakukan uji kointegrasi. Penelitian ini menggunakan metode Johansen Cointegration dalam melakukan pengujian kointegrasi. Terdapat hipotesis dalam pelaksanaan uji kointegrasi ini, dimana Ho diterima yang berarti tidak terjadi kointegrasi pada variabel dalam model tersebut. Kemudian H1 atau Ho ditolak yang berarti terjadi kointegrasi di dalam model tersebut. Suatu model dikatakan Ho ditolah apabila nilai probabilitas atau nilai kritisnya diatas $5 \%$ atau 0,05 .

Tabel 4. Uji Kointegrasi

\begin{tabular}{|l|l|l|l|l|}
\hline $\begin{array}{c}\text { Model } \\
\text { Penelitian }\end{array}$ & \multicolumn{1}{|c|}{ Variabel } & \multicolumn{1}{c|}{$\begin{array}{c}\text { Tingkat } \\
\text { Stasioneritas }\end{array}$} & \multicolumn{1}{c|}{$\begin{array}{c}\text { Hasil Uji } \\
\text { Kointegrasi }\end{array}$} & Metode \\
\hline NPF & $\begin{array}{l}\text { NPF, inflasi, lnKurs, } \\
\text { BIrate, rSBIS, FFR }\end{array}$ & Second Difference & $\begin{array}{l}\text { Tidak terjadi } \\
\text { kointegrasi }\end{array}$ & VAR \\
\hline ROA & $\begin{array}{l}\text { NPF, inflasi, lnKurs, } \\
\text { BIrate, rSBIS, FFR }\end{array}$ & Second Difference & $\begin{array}{l}\text { Tidak terjadi } \\
\text { kointegrasi }\end{array}$ & VAR \\
\hline ROE & $\begin{array}{l}\text { NPF, inflasi, lnKurs, } \\
\text { BIrate, rSBIS, FFR }\end{array}$ & Second Difference & Terjadi kointegrasi & VECM \\
\hline CAR & $\begin{array}{l}\text { NPF, inflasi, lnKurs, } \\
\text { BIrate, rSBIS, FFR }\end{array}$ & Level 1 & Terjadi kointegrasi & VECM \\
\hline FDR & $\begin{array}{l}\text { NPF, inflasi, lnKurs, } \\
\text { BIrate, rSBIS, FFR }\end{array}$ & Second Difference & Terjadi kointegrasi & VECM \\
\hline
\end{tabular}

Berikut adalah rangkuman hasil uji kointegrasi dan metode penelitian yang akan digunakan oleh setiap modelnya, berdasarkan kriteria-kriteria yang telah dipenuhi.

\subsection{Pembahasan Hasil Penelitian}

Berdasarkan uraian pada pokok pokok bahasan di atas, secara ringkas dapat disimpulkan sementara, yaitu bahwa Hasil IRF merespon suatu guncangan fluktuasi makroekonomi dalam negeri juga suku bunga dana Federal Reserve, sehingga yang menjadi tolok ukur kinerja keuangan bank umum syariah adalah yaitu NPF, ROA, ROE, CAR dan FDR. Guncangan pada inflasi direspon secara berbeda-beda dan cenderung berfluktuasi oleh kinerja keuangan perbankan syariah. NPF dan ROA merupakan dua variabel yang lebuh cepat stabil atau resisten terhadap guncangan inflasi serta menunjukan bahwa respon kedua rasio tersebut tidak bersifat permanen. Hal yang serupa pula terlihat pada respon CAR terhadap guncangan inflasi, yang sepanjang periode pada grafik menunjukan respon positif yang cenderung mendekati sumbu convergen walaupun pada akhir periode keenampuluh CAR masih menunjukan respon sebesar 0,09\%. Sedangkan hal yang berlainan ditunjukan oleh ROE dan FDR dimana terjadi fluktuasi yang cukup besar hingga periode ketigapuluh lima, bahkan respon ROE mereda dan cenderung stabil di periode ketigapuluh sembilan. Respon kedua indikator tersebut cenderung terjadi dalam jangka waktu yang panjang, karena hingga akhir periode keenampuluh ROE dan FDR masih merespon guncangan pada inflasi masing-masing sebesar $0,17 \%$ dan $0,7 \%$.

Variabel makroekonomi dalam negeri selanjutnya, adalah kurs atau nilai tukar US dolar terhadap rupiah. Seperti yang telah dijelaskan pada bab-bab sebelumnya, bahwa peneliltian ini menggunakan In atau logaritma natural dari nilai tukar mata uang rupiah dengan dolar Amerika Serikat yang hasilnya bahwa, guncangan yang terjadi pada kurs pada umumnya direspon secara fluktuasi signifikan pada awal-awal periode. NPF, ROA, dan CAR cenderung lebih cepat mencapai kestabilan dibandingkan dengan dua indikator lainnya yaitu beberapa periode setelah periode keduabelas. NPF dan ROA mencapai kestabilan dengan menunjukan angka yang mendekati $0 \%$ atau dalam gambar terlihat grafik yang berimpit dengan sumbu x. Nilai respon yang mendekati $0 \%$ menunjukan bahwa respon NPF dan ROA tidak bertahan dalam jangka waktu yang lama, dengan 
kata lain NPF dan ROA memiliki ketahanan atas guncangan yang terjadi pada variabel kurs. CAR relatif lebih cepat stabil dibandingkan dengan FDR dan ROE, tetapi CAR masih meninggalkan respon negatif sebesar 1,4\% sampai dengan akhir periode penelitian. Sedangkan ROE dan FDR terus mengalami fluktuasi sampai dengan akhir periode dengan menyisakan nilai respon di posisi negatif sekitar $1 \%$.

Guncangan pada suku bunga Bank Indonesia direspon secara berfluktuasi oleh kelima kinerja keuangan perbankan syariah.. Fluktuasi tersebut terjadi secara signifikan dari awal periode hingga kurang dari periode keduapuluh. Setelah periode tersebut respon NPF dan ROA terhadap guncangan pada BI rate cenderung stabil masing-masing pada periode keduabelas dan kedelapanbelas mendekati garis convergen. Semakin mendekatnya grafik kepada garis equilibrium atau convergen serta nilai respon yang semakin mengecil menuju $0 \%$ menunjukan bahwa respon dari NPF dan ROA tidak bersifat permanen. CAR dan FDR merespon guncangan pada variabel BI rate secara negatif, sedangkan ROA merespon secara positif dan respon tersebut bertahan sampai dengan akhir periode penelitian. NPF menjadi indikator kinerja keuangan perbankan syariah yang paling cepat menemui kestabilan dibandingkan dengan empat indikator lainnya. Sedangkan ROE dan FDR terus mengalami fluktuasi sampai dengan akhir periode penelitian.

Imbal hasil SBIS (rSBIS) direspon secara berfluktuatif oleh NPF dan ROA di duabelas periode pertama. Respon dari kedua indikator tersebut stabil mendekati garis convergen sampai dengan akhir periode. CAR merupakan variabel ketiga yang paling cepat mengalami kestabilan, kestabilan dicapai pada periode keduapuluh dengan respon positif. Kemudian FDR merespon guncangan yang terjadi pada rSBIS dengan pergerakan fluktuasi yang signifikan pada duabelas periode pertama, setelah periode tersebut fluktuasi mereda walaupun di akhir periode masih menyisakan respon positif sebesar $0,68 \%$. Sedangkan ROE menjadi variabel yang fluktuasi responnya terjadi sepanjang periode dan fluktuasi dengan nilai yang besar baru mulai menipis di periode keemaptpuluhtujuh. Sampai akhir periode nilai respon yang diberikan oleh ROE adalah $1,35 \%$ terbesar diantara respon guncangan yang diberikan indikator kinerja keuangan perbankan syariah lainnya.

Variabel makroekonomi terakhir adalah suku bunga dana Federal Reserve (FFR), serupa dengan respon guncangan pada variabel makroekonomi dalam negeri sebelumnya bahwa NPF dan ROA cenderung merespon guncangan pada FFR secara singkat dan lebih cepat stabil mendekati sumbu convergen. Hal yang berlainan ditunjukan oleh ROE dan FDR, karena respon atas guncangan FFR bertahan lama sampai dengan akhir periode. ROE mengalami fluktuasi sepannjang periode di posisi positif. Serupa dengan respon ROE bahwa FDR pun mengalami fluktuasi respon yang berkepanjangan, dimana pada periode keenampuluh FDR merespon guncangan tersebut sebesar $0,68 \%$. Kemudian CAR seperti yang telah dijelaskan sebelumnya bahwa model CAR tidak dapat diestimasi dengan variabel FFR, karena terjadi near singular matrix.

Hasil FEVD menunjukan bahwa nilai tukar mata uang rupiah dengan dolar Amerika Serikat (lnKurs) memberikan kontribusi pengaruh terbesar terhadap perubahan NPF, yaitu sebesar 3,9\%. Sedangkan perubahan yang terjadi pada ROA besar dipengaruhi oleh kontribusi yang diberikan oleh imbal hasil SBIS sebesar 3,57\% yang terjadi pada periode keenambelas. Suku bunga acuan Bank Indonesia atau BI rate memberikan kontribusi pengaruh terbesar pada perubahan ROE dan FDR, masing-masing sebesar $1,65 \%$ dan 4,05\% sebagai nilai kontribusi tertingginya. Kemudian yang terakhir adalah perubahan pada CAR turut mendapat kontribusi pengaruh terbesar atas guncangan yang terjadi pada kurs yaitu sebesar $0,99 \%$ yang terjadi pada periode kelima. 
Tabel 4. Kinerja Keuangan BUS di Indonesia

\begin{tabular}{|c|c|c|c|c|c|}
\hline & NPF & ROA & ROE & CAR & FDR \\
\hline 2014 & 4,95 & 0,41 & 6,74 & 15,74 & 86,66 \\
\hline 2015 & 4,48 & 0,49 & 2,34 & 15,02 & 88,03 \\
\hline 2016 & 4,42 & 0,63 & $-0,12$ & 16,63 & 85,99 \\
\hline 2017 & 4,76 & 0,63 & 2,91 & 17,91 & 79,61 \\
\hline 2018 & 4,27 & 1,18 & 5,92 & 19,82 & 78,88 \\
\hline
\end{tabular}

Sumber: Statistik Perbankan Syariah - Otoritas Jasa Keuangan, diolah

Melalui tabel yang tertera diatas dapat dlihat bahwa NPF relatif stabil dan BUS berhasil untuk menjaga nilai NPF nya dibawah 5\% sesuai batas atas yang telah ditetapkan pada Peraturan Otoritas Jasa Keuangan (POJK) Nomor 15/POJK.03/2017. Sama halnya dengan ROA dan CAR yang menunjukan trend meningkat selama lima tahun terakhir, dimana bank umum syariah telah memenuhi bahkan melampaui batas minimum CAR yang ditetapkan dalam POJK yaitu 8\%. Berbanding terbalik dengan FDR yang justru menunjukan trend menurun, sedangkan ROE mengalami fluktuasi dalam lima tahun terakhir.

Hasil penelitian ini secara keseluruhan menunjukan, bahwa NPF dan ROA relatif lebih cepat untuk mencapai kestabilan serta tidak menunjukan respon yang permanen atau tidak berjangka panjang apabila terdapat suatu guncangan yang terjadi pada variabel makroekonomi serta FFR dalam penelitian. Hal tersebut mengindikasikan bahwa kinerja keuangan perbankan syariah dalam hal ini NPF dan ROA resisten atau tahan terhadap fluktuasi yang terjadi pada makroekonomi dalam negeri dan suku bunga dana Amerika Serikat. Hal ini sebelumnya telah disampaikan dalam penelitian yang dilakukan oleh Faiz (2011), NPL pada bank syariah atau NPF cenderung resisten terhadap krisis keuangan. Serupa dengan penelitian Nugraheni (2011) bahwa tidak hanya NPF yang hasilnya lebih cepat stabil apabila terdapat guncangan yang terjadi pada makroekonomi tetapi ROA pun ternyata resisten terhadap guncangan tersebut.

CAR pula relatif cepat untuk mencapai kestabilan, tetapi ternyata CAR merespon suatu guncangan terutama pada variabel makroekonomi dalam negeri dengan jangka waktu yang panjang dalam hal ini selama enampuluh periode. Sedangkan ROE dan FDR merespon suatu guncangan untuk mencapai kestabilan setelah terjadainya fluktuasi cenderung lebih lama dibandingkan dengan tiga rasio sebelumnya. ROE dan FDR pun meninggalkan respon berjangka panjang terhadap fluktuasi yang terjadi pada makroekonomi dalam negeri. Zarrouk dalam penelitiannya tahun 2014 menyatakan bahwa institusi keuangan syaroah termasuk didalamnya perbankan syariah dalam hal profitabilitas dan likuiditas perbankan menurun secara drastis setelah terjadi krisis atau guncangan, dengan kata lain perbankan tidak imun dengan guncangan keuangan atau makroekonomi global. Penelitian ini termasuk menjelaskan ROAE atau Return on Average Equity sebagai salah satu variabel yang mewakili profitabilitas dan LDR pada bank syariah untuk mewakili likuiditas perbankan.

Implikasi bagi pemerintah sebagai pemangku kebijakan serta pihak yang memiliki wewenang untuk menjaga stabilitas kondisi makroekonomi dalam negeri, yang dalam hal ini diwakili oleh Bank Indonesia adalah sesuai dengan tujuannya untuk menstabilkan tingkat laju inflasi serta nilai tukar rupiah dengan mata uang asing atau kurs. Tidak hanya itu, Bank Indonesia pula memiliki instrumen moneter berupa suku bunga acuan Bank Indonesia dan Sertifikat Bank Indonesia Syariah yang dalam penelitian telah disampaikan pula dapat memicu respon dari kinerja keuangan bank umum syariah. Dimana dalam menentukan kebijakan diharapkan pemerintah maupun Bank Indonesia tetap mempertimbangkan dampak atas suatu kebijakan tersebut pada stabilitas dari industri perbankan dalam hal ini khususnya bank umum syariah. Hal ini pula tidak terlepas dari kerja sama 
atau koordinasi dengan instansi terkait seperti Otoritas Jasa Keuangan (OJK) sebagai pihak yang bertanggung jawab atas pengawasan pada operasional perbankan di Indonesia, melalui aturanaturan yang dikeluarkan dalam lingkup mikroprudensial.

Bank umum syariah pula dapat menggunakan peluang dengan maraknya penggunaan teknologi informasi dalam hal ini lebih dikenal dengan dalam lingkup keuangan sebagai Fintech (Financial Technology) menarik minat masyarakat untuk menggunakan jasa bank syariah yang diharapkan dengan penggunaan fintech yang optimal dapat meningkatkan pangsa pasar dari bank umum syariah sendiri, khususnya di Indonesia.

\section{Penutup}

Pada penelitian tugas akhir ini, penulis menggunakan beberapa rasio keuangan untuk mewakili kinerja keuangan bank umum syariah di Indonesia. Terdapat lima indikator yang digunakan yaitu Non Performing Financing (NPF), Return on Asset (ROA), Return on Equity (ROE), Capital Adequacy Ratio (CAR), dan Financing to Deposit Ratio (FDR). Guna melihat resistensi bank umum syariah Indonesia terhadap fluktuasi makroekonomi dalam negeri dan luar negeri, penulis menggunakan beberapa sampel sebagai variabel makroekonomi dalam negeri yaitu inflasi, nilai tukar (kurs), suku bunga acuan Bank Indonesia (BI rate), imbal hasil SBIS (rSBIS) dan suku bunga dana Federal Reserve (FFR) untuk mewakili variabel makroekonomi luar negeri.

Berdasarkan rumusan masalah yang telah disampaikan pada pendahuluan, penulis menggunakan hasil pengujian IRF (Impulse Response Function) untuk melihat respon dari kinerja keuangan bank umum syariah terhadap fluktuasi yang terjadi pada variabel makroekonomi. Respon kinerja keuangan ini yang pada akhirnya menjadi sumber informasi untuk melihat ketahanan bank umum syariah di Indonesia. Dalam pengujian tersebut didapatkan sebuah kesimpulan bahwa NPF dan ROA bank umum syariah di Indonesia resisten terhadap fluktuasi atau guncangan yang terjadi pada makroekonomi dalam negeri dan FFR. CAR menunjukan respon yang berkepanjangan serupa dengan ROE dan FDR bank umum syariah yang cenderung tidak resisten terhadap fluktuasi yang terjadi pada makroekonomi dalam negeri dan FFR.

Dikarenakan adanya keterbatasan teknis dalam penelitian ini, diharapkan untuk penelitiannya selanjutnya yang hendak mengukur ketahanan dari bank umum syariah khususnya di Indonesia dapat menggunakan beberapa variabel ini sebagai indikator dari krisis perbankan seperti yang telah disampaikan pada bab sebelumnya, Hadad, dkk (2003) menyebutkan bahwa variabel-varibel tersebut diantaranya konsumsi swasta, Dana Pihak Ketiga (DPK), Real Effective Exchange Rate (REER), Produk Domestik Bruto Riil, Investasi, Kredit kepada sektor swasta, dan Inflasi.

Selain itu berdasarkan penelitian Zarouk (2014) untuk mengamati performa dari bank khususnya bank syariah dapat diwakili oleh beberapa kategori yaitu profitabilitas, likuiditas, risk and solvency, dan efisiensi dimana variabel-variabelnya pula terlah disampaikan pada tabel Penelitian Terdahulu.

\section{Daftar Pustaka}

(IBI), I. B., \& (LSP), L. S. (2014). Mengenal Operasional Perbankan I. Jakarta: PT Gramedia Pustaka Utama.

Ascarya. (2002). Seri Kebanksentralan: Instrumen-Instrumen Pengendalian Moneter. Jakarta: Bank Indonesia.

Basuki, A. T., \& Prawoto, N. (2016). Analisis Regresi: Dalam Penelitian Ekonomi dan Bisnis (Dilengkapi Apliasi SPSS dan Eviews). Jakarta: PT RajaGrafindo Persada .

Cihak, M., \& Hesse, H. (2008). Islamic Banks and Financial Stability: An Empirical Analysis. IMF Working Paper. 
Faiz, I. A. (2010). Ketahanan Kredit Perbankan Syariah Terhadap Krisis Keuangan Global. La_Riba Jurnal Ekonomi Islam.

Farooq, M., \& Zaheer, S. (2015). Are Islamic Banks More Resilient during Financial Panics? IMF Working Paper.

Hadad, M. D., Santoso, W., \& Arianto, B. (2003). Indikator Awal Krisis Perbankan.

Indonesia, m. d. (2018, Oktober 19). Hanya 3,1 Persen Penduduk Produktif di RI yang Wirausaha. Dipetik Mei 06, 2019, dari CNN Indonesia: https://www.cnnindonesia.com/ekonomi/20181018210657-92-339664/hanya-31persen-penduduk-produktif-di-ri-yang-wirausaha

Kariyoto. (2017). Analisa Laporan Kenangan. Malang: UB Media.

Mankiw, N. G. (2017). Macroeconomics Seventh Edition. New York: Worth Publishers.

mkl, \& hds. (2015, April 14). Menkeu Bambang: Bank Syariab Lebib Taban Menghadapi Krisis. Dipetik Januari 25, 2019, dari detikfinance: https://finance.detik.com/moneter/d2886801/menkeu-bambang-bank-syariah-lebih-tahan-menghadapi-krisis

Nugraheni, S. R. (2011). Analisis Daya Taban Perbankan Syariah Terbadap Fluktuasi Ekonomi di Indonesia. Bogor: Institut Pertanian Bogor.

Online, I. S. (2010, Oktober 4). IMF Survey: Islamic Banks: More Resilient to Crisis? Dipetik Oktober 13, 2018, dari IMF: https://www.imf.org/en/News/Articles/2015/09/28/04/53/sores100410a

Philadelphia, F. R. (2014). Federal Reserve System: The First 100 Years. Federal Reserve Bank of Philadelphia.

Prasetyo, P. E. (2016). Fundamental Makro Ekonomi. Yogyakarta: Beta Offset.

PT Bursa Efek Indonesia. (2018). IDX Fact Book. Jakarta: PT Bursa Efek Indonesia.

Setiawan, S. R. (2017, Maret 15). The Fed Akan Naikkan Suku Bunga, Apa Dampaknya Bagi Perbankan? Dipetik Januari 25, 2019, dari kompas.com: https://bisniskeuangan.kompas.com/read/2017/03/15/193000626/the.fed.akan.naikkan .suku.bunga.apa.dampaknya.bagi.perbankan.

Suwiknyo, D. (2016). Analisa Laporan Keuangan Perbankan Syariah. Yogyakarta: Pustaka Pelajar.

Tripuspitorini, F. A., \& Setiawan, S. (2020). Pengaruh faktor makroekonomi terhadap pertumbuhan dana pihak ketiga pada bank umum syariah di Indonesia. Jurnal Riset Akuntansi dan Keuangan, 8(1), 121-132.

wan. (2019, Februari 01). Jumlah Startup di Indonesia Melonjak. Dipetik Mei 06, 2019, dari jpnn.com: https://www.jpnn.com/news/jumlah-startup-di-indonesia-melonjak

Z., W. (2012). Pembiayaan Bank Syariah. Jakarta: PT Gramedia Pustaka Utama.

Zarrouk, H. (2014). Impact of The International Financial Crisis on The Performance of Islamic Banks in MENA Countries. Contemporary Studies in Economic and FInancial Analysis, Volume 95, 45-69. 